\title{
Hydrolysis Kinetics of Oil Palm Empty Fruit Bunch in Ionic Liquids and Cellulase Integrated System
}

\author{
Amal A. M. Elgharbawy ${ }^{1}$, Md. Zahangir Alam², Muhammad Moniruzzaman ${ }^{3}$, Hamzah Mohd. Salleh ${ }^{1}$ \\ ${ }^{1}$ International Institute for Halal Research and Training (INHART), International Islamic University Malaysia, Kuala \\ Lumpur, Malaysia. \\ ${ }^{2}$ Department of Biotechnology Engineering, Kulliyyah of Engineering, International Islamic University Malaysia, Kuala \\ Lumpur, Malaysia. \\ ${ }^{3}$ Chemical Engineering Department, Centre of Research in Ionic Liquids (CORIL), Universiti Teknologi PETRONAS, \\ Bandar Seri Iskandar, Malaysia. \\ Correspondence: Amal A. M. Elgharbawy, International Institute for Halal Research and Training (INHART), \\ International Islamic University Malaysia, P.O. Box 10, Kuala Lumpur 50728, Malaysia. Tel (Office): +60 3 \\ 6196-5590/6496. E-mail: amal.elgharbawy@gmail.com
}

\author{
Received: June 18, 2019 Accepted: July 18, 2019 Online Published: July 26, 2019 \\ doi:10.5539/ijc.v11n2p95 URL: https://doi.org/10.5539/ijc.v11n2p95
}

\begin{abstract}
Ionic liquids (ILs) are developing as potential solvents in lignocellulose solvation, which enables cellulase accessibility into the substrate. Nevertheless, ILs could result in enzyme deactivation because of the high polarity. Therefore, developing a system of ILs-compatible cellulase (IL-E) to promote lignocellulose conversion into sugars is a challenge in ILs applications. This study used an IL-E to attain high conversion yield of sugars from oil palm empty fruit bunch (EFB). Cellulase ( $\mathrm{Tr}$-Cel) from Trichoderma reesei was stable in the ILs, 1-ethyl-3-methyl imidazolium diethyl phosphate [EMIM]DEP and choline acetate [Cho]OAc. The inhibition and deactivation of cellulase were evaluated using the model substrate, carboxymethyl cellulose (CMC) and EFB as a lignocellulosic material to assess the hydrolytic activity. The enzyme kinetics revealed that [Cho]OAc acted as a noncompetitive inhibitor. Additionally, [EMIM]DEP may not be considered as an inhibitor as it increases the $V_{\max }$ and does not significantly affect the $K_{\mathrm{M}}$. In both cases, the study proved that IL did not result in a severe loss of cellulase activity, which is a promising outcome for one-pot hydrolysis of lignocellulosic materials.
\end{abstract}

Keywords: affinity, activity, ionic liquid, inhibition, cellulase, lignocellulose, hydrolysis

\section{Introduction}

It is prominent that lignocellulose is one of the most beneficial and important renewable biomaterials which offers a sustainable substitute for fossil fuels resources (Varanasi et al., 2012) as it consists the desirable carbohydrates, cellulose and hemicellulose (Mamman et al., 2008). Oil palm empty fruit bunch (EFB) is the prime solid waste after oil extraction. Holocellulose contributes to $60-70 \%$ of the total weight of EFB. A biological conversion is required to utilize these components, however, as a result of the complex structure, high cost and lengthy treatment are required for the processing (Alonso, Bond, \& Dumesic, 2010). Diverse approaches have been implemented in the pretreatment of lignocellulose including chemical (Pellera \& Gidarakos, 2018) such as acidic (Harun \& Danquah, 2011) and alkali treatment (Zainan, Alam, \& Al-Khatib, 2013), physical or mechanical treatment (Barakat et al., 2014), physicochemical (Brodeur et al., 2011) and biological methods (Balat, 2011) using microbes (Alam, Kabbashi, \& Hussin, 2009; Galbe \& Zacchi, 2007). Nevertheless, these methods are associated with various disadvantages as they consume high energy, might be toxic, or may be pricey (Muhammad et al., 2014; Yang et al., 2010). More drawbacks include disposal challenge, cost of recovery and slow rate of reaction (Balat, 2011). In contrast to chemical hydrolysis, enzymatic hydrolysis is an eco-friendly substitute (Salihu \& Alam, 2015). Though, conventional solvents could result in loss of enzyme activity and are associated with the environmental threats which directed the concern towards green solvents. In this context, ionic liquids (ILs) are good solvents for complex carbohydrates and offer many attractive properties such as stabilizing enzymes (Elgharbawy, Alam, Moniruzzaman, \& Goto, 2016; Fu, Mazza, \& Tamaki, 2010). Wang et al. (Wang, Radosevich, Hayes, \& Labbé, 2011) reported that some cellulases were stabilized in IL when examined in [EMIM]OAc (15\%) in the saccharification process of yellow poplar biomass, and [EMIM]OAc (10-20\%) for enzymatic hydrolysis of switchgrass (Shi et al., 2013). Additionally, many studies have reported cellulases stability in systems that 
are IL-E compatible, for instance, cholinium-based ILs (Ninomiya et al., 2015). Furthermore, single-step hydrolysis is the desired process where IL pretreatment of lignocellulose is integrated with enzymatic hydrolysis for bioethanol production, as it eliminates the regeneration stage of the cellulose.

Two main paths may demonstrate the enzyme-catalyzed hydrolysis upon biomass IL-pretreatment, which include the regeneration of cellulose from the IL solution, to undergo enzymatic hydrolysis (Tan, Lee, \& Mohamed, 2011; Zhao et al., 2009). The second path is regarded as a single-step process where the hydrolysis is directly performed in the IL in a water-based buffer solution by cellulase enzymes (Gunny, Arbain, Edwin Gumba, Jong, \& Jamal, 2014). Various ILs showed promising results in lignocellulose structure modification and lignin removal, such as choline acetate [Cho]OAc (Asakawa, Kohara, Sasaki, Asada, \& Nakamura, 2015). A group of researchers have tried to use IL-surfactant ([BMIM]Cl+ PEG-8000) to facilitate sugarcane bagasse dissolution using both cellulase and xylanase, which are generated in house from Aspergillus assiutensis VS34. The bagasse was pretreated at $90{ }^{\circ} \mathrm{C}$ for $2 \mathrm{~h}$, followed by enzymatic hydrolysis with both enzymes. Ninety percent of the activity was maintained in the IL (Sharma, Nargotra, \& Bajaj, 2019). This shows the ability of IL to cater for compatibility with some enzymes (Elgharbawy, Alam, Moniruzzaman, et al., 2016; Ibrahim, Moniruzzaman, Yusup, \& Uemura, 2015). On the contrary, Cellic ${ }^{\circledR}$ Htec2 cellulase acting on $\mathrm{CMC}$ was deactivated in the presence of [BMIM]Cl but without surfactant, showing that [BMIM]Cl is a competitive inhibitor (Nemestóthy et al., 2017).

\section{Method}

\subsection{Materials}

Sime Darby Plantation, Malaysia provided the oil palm empty fruit bunch (EFB) raw material used in this study. Cellulase (Tr-Cel) from Trichoderma reesei ATCC 26921, lyophilized powder ( $\geq 1$ unit/mg solid) was purchased from Sigma-Aldrich, USA. Choline acetate [Cho]OAc was synthesized as reported in the previous publication (Elgharbawy, Alam, Jamal, Kabbashi, \& Moniruzzaman, 2016). 1-Ethyl-3-methyl imidazolium diethyl phosphate [EMIM]DEP was obtained from Merck, Germany.

\subsection{Determination of Kinetics Parameters of Tr-Cel with CMC and EFB}

$\mathrm{Tr}$ - $\mathrm{Cel}$ was incubated for $60 \mathrm{~min}$ in various concentrations of ILs (10, 20, 40, 60, 80 and 100\%). After incubation, the solution was subjected to cellulase activity assay using CMC as described by Salvador et al. (Salvador, Santos, \& Saraiva, 2010).

Dry EFB (500 mg) was weighed in a glass vial, and following IL addition the mixture was incubated for $60 \mathrm{~min}$ at $90{ }^{\circ} \mathrm{C}$, cooled to room temperature and a buffer solution (sodium citrate buffer $\mathrm{pH} 4.8 \pm 0.2,50 \mathrm{mM}$ ) was added to the tubes to attain a solution with $10 \% \mathrm{IL}$. Lastly, the cellulase ( $\mathrm{Tr}$ - $\mathrm{Cel}$ ) was added to start the enzymatic hydrolysis.

\subsection{Determination of Kinetics Parameters of Tr-Cel with CMC and EFB in IL}

The kinetic parameters of $\mathrm{Tr}$ - $\mathrm{Cel}$ were studied by monitoring the IL-E at various concentrations with $500 \mathrm{mg}$ of both $\mathrm{CMC}$ and $\mathrm{EFB}$ in $50 \mathrm{mM}$ sodium citrate buffer $\left(60 \mathrm{~min}, 50^{\circ} \mathrm{C}, \mathrm{pH} 4.8 \pm 0.2\right)$ and different loading of the enzyme (10, 20, 30, 40 and 50 units). The linear equation of Michaelis-Menten was used to calculate the parameters $\left(V_{\max }\right.$ and $\left.K_{\mathrm{M}}\right)$, graphically based the velocity $(V)$ of the enzyme-catalyzed reaction, at different substrate concentrations $[S]$. The enzyme activity was fixed at 50 units $\left(50 \mathrm{FPU} \mathrm{g}^{-1}\right)$ while varying the loading of substrates 100, 300, 500, 700 and 1000 $\mathrm{mg}$ and then measuring the concentration of sugar.

CMC substrate was prepared at these concentrations: 1.0, 2.0, 3.0, 4.0, 5.0, 6.0, 8.0, $10.0 \mathrm{~g} / \mathrm{L}$. The initial enzyme velocity was assessed using cellulase activity assay method (DNS reagent) (Zhang, Hong, \& Ye, 2009). The reciprocal of substrate concentration 1/[S] (X-axis) and the reciprocal of initial enzyme velocity 1/V as (Y-axis), were plotted to obtain the Lineweaver-Burk double reciprocal graph. Lineweaver-Burk model was used as it is a common tool to determine important terms in enzyme kinetics, such as $V_{\max }$ and $K_{\mathrm{M}}$.

For EFB substrate, enzymatic activity was analyzed using linear Michaelis-Menten model to determine the kinetics parameters $V_{\max }$ and $K_{\mathrm{M}}$. The model with the largest determination coefficient $\left(\mathrm{R}^{2}\right)$ was regarded as the best fitted to describe the enzyme kinetics.

\section{Results and Discussion}

\subsection{Determination of Kinetics Parameters of Tr-Cel with CMC and EFB}

The main function of an enzyme is to accelerate the rate of reaction. Kinetic parameters are essential to the understanding of enzyme activity and function. Figure 1 shows the kinetic models of $\mathrm{Tr}$ - $\mathrm{Cel}$ using CMC as a model substrate for the linear Michaelis-Menten model. The kinetic parameters for each linear model are summarized in Table 1. 
Table 1. Kinetics parameters for $\mathrm{Tr}$ - $\mathrm{Cel}$ with two different substrates: EFB and CMC

\begin{tabular}{lllllll}
\hline Model & \multicolumn{2}{l}{$K_{\mathrm{M}}\left(\mathrm{mg} \cdot \mathrm{mL}^{-1}\right)$} & \multicolumn{2}{l}{$V_{\max }\left(\mathrm{mg} \mathrm{mL}^{-1} \mathrm{~min}^{-1}\right)$} & & $\mathrm{R}^{2}$ \\
\hline \multicolumn{1}{c}{ Substrate } & EFB & CMC & EFB & CMC & EFB & CMC \\
\hline Lineweaver-Burk & 0.184 & 0.045 & 11.19 & 68.49 & 0.9592 & 0.9059 \\
Hanes-Woolf & 1.00 & 1.00 & 1.345 & 9.65 & 0.9961 & 0.9209 \\
Eadie-Hofstee & 48.38 & 18.18 & 29.63 & 37.43 & 0.6058 & 0.8736 \\
\hline
\end{tabular}

The value of $K_{\mathrm{M}}$ mainly measures the enzyme affinity to a substrate. The smaller the $K_{\mathrm{M}}$ value, the greater the affinity of the enzyme for its substrate while the $V_{\max }$ parameter is an indication of the maximum velocity once the substrate occupies all the active sites of the enzyme. Usually, most of the $K_{\mathrm{M}}$ values are expressed in $\mathrm{mM}\left(\mathrm{mmol}\right.$. $\left.\mathrm{L}^{-1}\right)$ and the value of $K_{\mathrm{M}}$ is converted from mg. $\mathrm{mL}^{-1}$ to $\mathrm{mM}$ or $\mu \mathrm{M}$ using the molecular weight of the substrate. However, the compared substrate (EFB) does not have a well-recognized molecular weight; hence, the values were expressed in $\mathrm{mg} \mathrm{mL}^{-1}$.

Comparing the $K_{\mathrm{M}}$ and $V_{\max }$ values in case of CMC, using Hanes-Woolf and Lineweaver-Burk models, a higher value of $V_{\max }$ was obtained when the enzyme was modelled with Lineweaver-Burk $\left(68.49 \mathrm{mg} \cdot \mathrm{mL}^{-1} \cdot \mathrm{min}^{-1}\right)$. Likewise, $K_{\mathrm{M}}$ value was the lowest when the enzyme was modelled with Lineweaver-Burk. Eadie-Hoftsee model did not show a good fit for the enzyme with either substrate. The plots can be seen in Figure 1.

In comparison, the EFB showed a good fit with both Lineweaver-Burk and Hanes-Woolf, although the values of $K_{\mathrm{M}}$ and $V_{\max }$ were more comparable with Lineweaver-Burk. It can also be seen that $K_{\mathrm{M}}$ resulted in the same values in both cases when modelling the enzyme with Hanes-Woolf; therefore, Lineweaver-Burk was used to observe the contrast trend. The values varied with EFB as the enzyme fitted into both Lineweaver-Burk and Hanes-Woolf models with high $\mathrm{R}^{2}$ values. It can be seen that the $K_{\mathrm{M}}$ obtained was similar in the Hanes-Woolf model for both substrates although $V_{\max }$ was greater with CMC. 
(a)

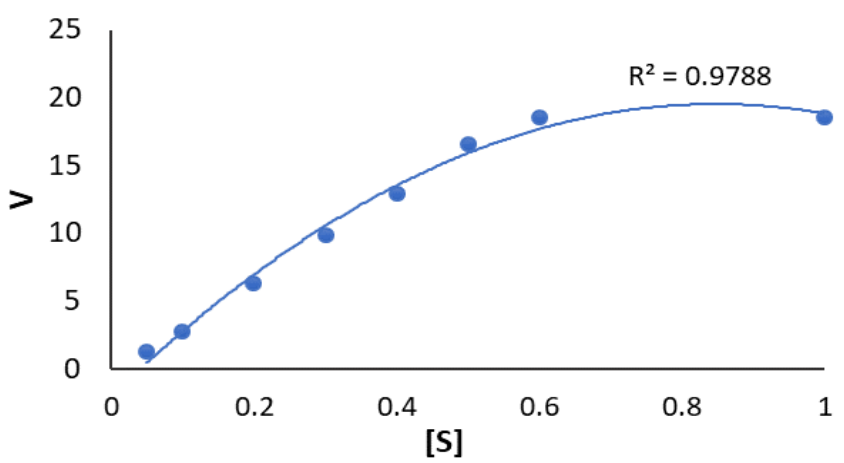

(b)

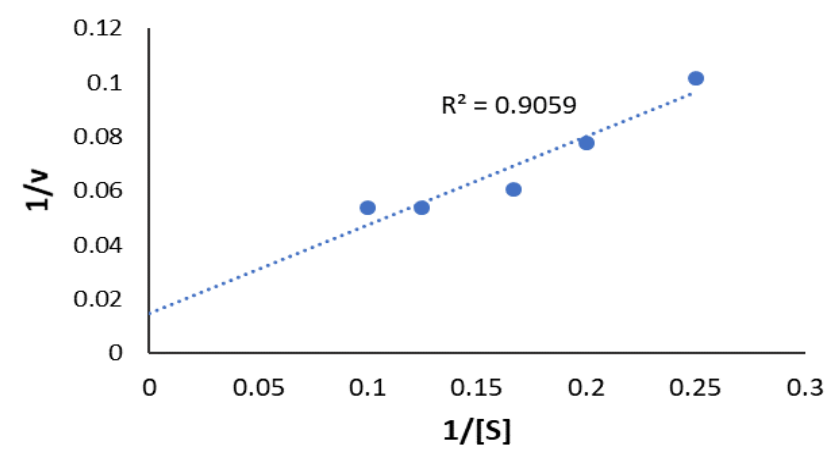

(c)

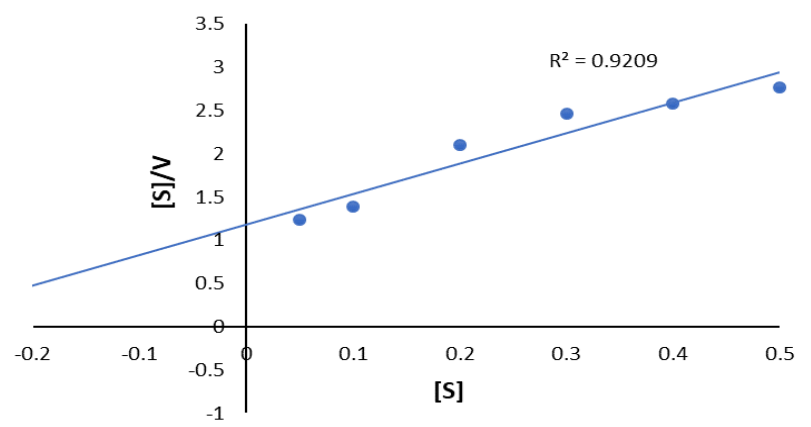

(d)

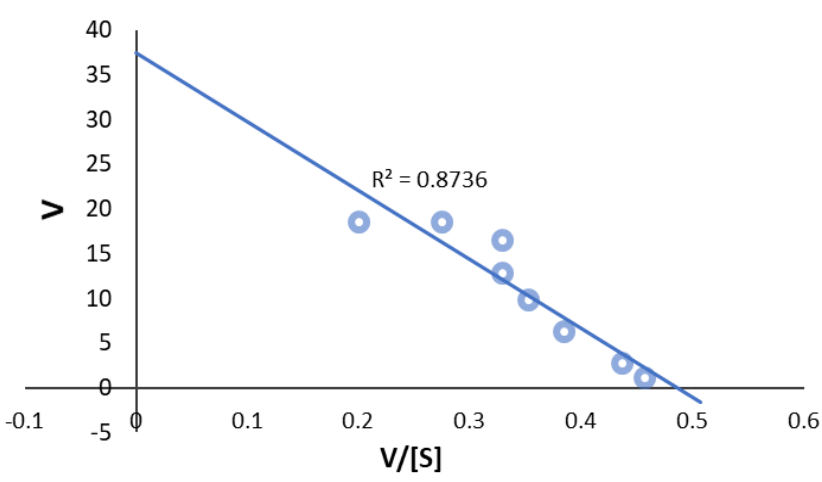

Figure 1. Kinetic model of (a) Michaelis-Menten hyperbolic plot, (b) Lineweaver-Burk plot, (c) Hanes-Woolf, (d) Eadie-Hofstee for in-house produced cellulase ( $\mathrm{Tr}$ - $\mathrm{Cel}$ ) using $\mathrm{CMC}$ as the substrate model, $[\mathrm{S}]=$ substrate concentration $\left(\mathrm{mg} \cdot \mathrm{mL}^{-1}\right), V=$ reaction velocity $\left(\mathrm{mg} \cdot \mathrm{mL}^{-1} \mathrm{~min}^{-1}\right) \cdot \mathrm{R}^{2}=$ coefficient of determination 
In this case study, it appears that the enzyme has more affinity towards CMC compared to EFB. This, to a great extent, could be explained as CMC has always been a model substrate for cellulases, and is considered as a good substrate (Wang, Post, Mayes, Frerichs, \& Sindhu, 2012). The lower $K_{\mathrm{M}}$ might also be related to the complex structure of the lignocellulosic material. Adsorption of lignin to the surface of cellulase might occur in the case of EFB which occupies the active site in the absence of the IL (Noori \& Karimi, 2016).

\subsection{Determination of Kinetics Parameters of Tr-Cel with CMC and EFB in IL}

Pretreatment with IL has been regarded as a promising approach that promotes the lignocellulose saccharification; nevertheless, the presence of IL in the medium could inhibit the function of cellulase. Hence, an investigation is required on the occurrence of inhibition by measuring both the reaction velocity and enzyme affinity to the substrate. Consequently, the kinetic parameters were assessed in the presence and in the absence of the ILs to describe the IL impact on the activity of cellulase during the one-step hydrolysis. The inhibition trend (Figure 2 and Figure 3 ) shows the pattern of inhibition of both [EMIM]DEP and [Cho]OAc, on the cellulase for the 60 min hydrolysis of CMC and EFB.

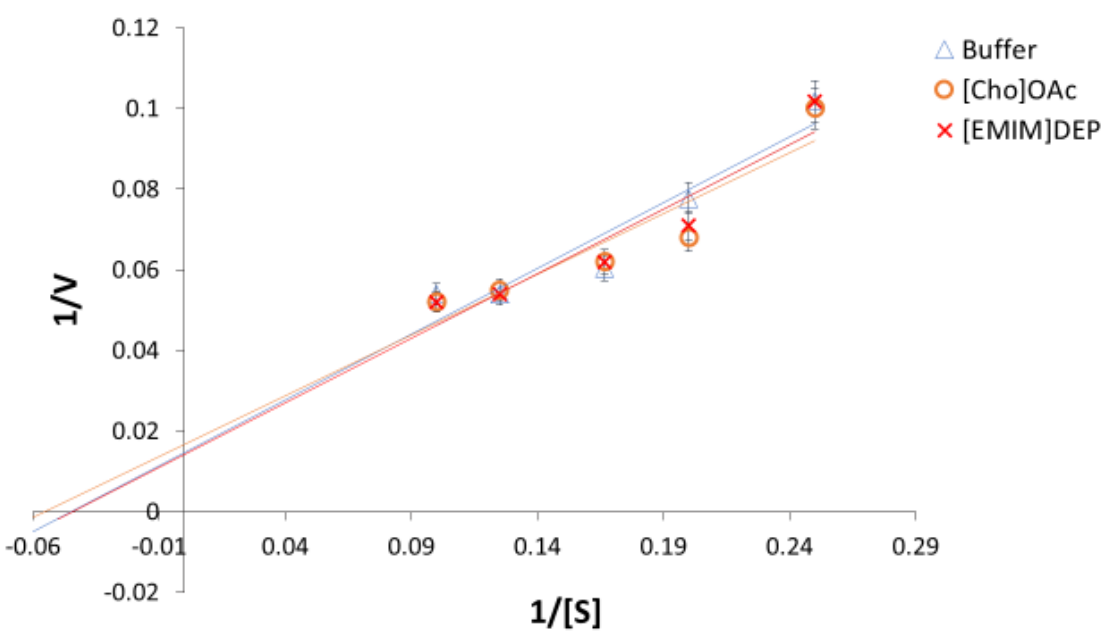

Figure 2. Lineweaver-Burk plot for the inhibition trend of cellulase in [EMIM]DEP, [Cho]OAc compared to buffer solution using carboxymethyl cellulose $(\mathrm{CMC})$ as the substrate for hydrolysis. $[\mathrm{S}]=$ substrate concentration $\left(\mathrm{mg}^{\mathrm{m}} \mathrm{mL}^{-1}\right)$, $V=$ reaction velocity $\left(\mathrm{mg} . \mathrm{mL}^{-1} \mathrm{~min}^{-1}\right)$. Conditions: pretreatment: $90^{\circ} \mathrm{C}, 60 \mathrm{~min}$; enzymatic hydrolysis: $\mathrm{pH} 4.8 \pm 0.2,50$ $\left.\mathrm{mM}, 50{ }^{\circ} \mathrm{C}, 60 \mathrm{~min}, 50 \mathrm{FPU} . \mathrm{g}^{-1}\right)$ 


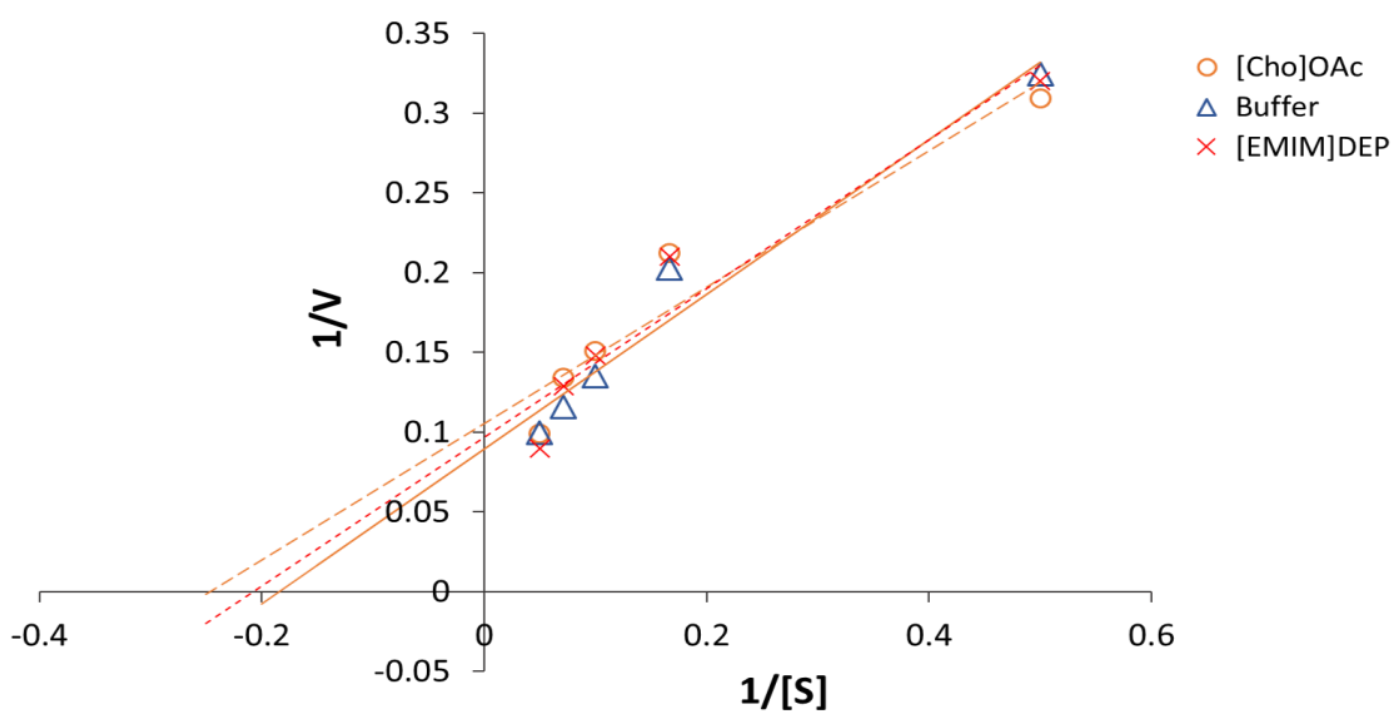

Figure 3. Lineweaver-Burk plot for the inhibition trend of cellulase in [EMIM]DEP, [Cho]OAc compared to buffer solution using EFB as the substrate for hydrolysis. $[\mathrm{S}]=$ substrate concentration $\left(\mathrm{mg} \mathrm{mL}{ }^{-1}\right), V=$ reaction velocity $\left(\mathrm{mg} . \mathrm{mL}^{-1}\right.$ $\left.\min ^{-1}\right)$

ILs resemble the mixed inhibitors where it is thought to occur when the inhibitor (IL) binds at a separate site other than the active site to either the enzyme-substrate complex or free enzyme (Figure 4).

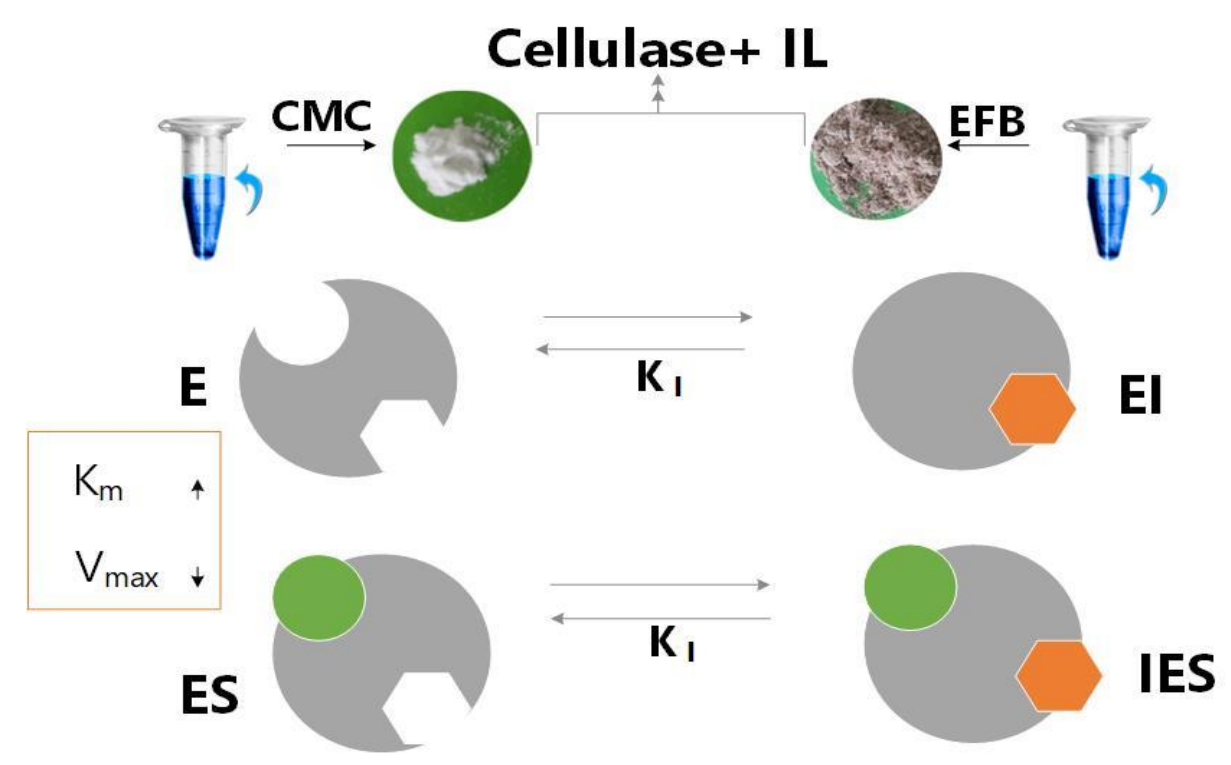

Figure 4. Illustration of mixed non-competitive inhibition in the cellulase-IL system

We concluded that the inhibitor fits reversible, mixed inhibition in which is recognized when the $K_{\mathrm{M}}$ and $V_{\max }$ are both affected. It can be seen that $V_{\max }$ is reduced as in noncompetitive inhibition whereas $K_{\mathrm{M}}$ increased slightly, which can be described by mixed inhibition. The maximum velocity decreased when the hydrolysis was conducted in choline acetate [Cho]OAc, however, $K_{\mathrm{M}}$ slightly increased, which points to less affinity towards the substrate. As calculated from the linear plot, $K_{\mathrm{M}}$ rose from 0.045 to $0.056 \mathrm{mg}$. mL ${ }^{-1}$ while $V_{\max }$ got reduced from 68.49 to $59.88 \mathrm{mg}$. mL $\mathrm{min}^{-1}$. Therefore, it supports the hypothesis of mixed inhibition as both $K_{\mathrm{M}}$ and $V_{\max }$ changed. In the presence of [EMIM]DEP, the velocity of cellulase slightly increased to $70.42 \mathrm{mg} . \mathrm{mL}^{-1} \mathrm{~min}^{-1}$ when $K_{\mathrm{M}}$ was not significantly affected. 
The reaction sequence can be written as in Scheme 1 (Henderson, 1972):

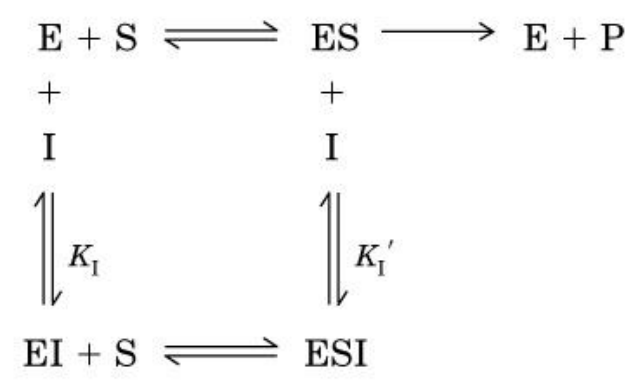

Scheme 1. Enzyme reaction sequence in the presence of the inhibitor (IL) (Henderson, 1972)

At equilibrium, $K_{\mathrm{M}}$ can be expressed as:

$$
\begin{aligned}
K_{\mathrm{M}} & =\frac{[\mathrm{E}][\mathrm{S}]}{[\mathrm{E} . \mathrm{S}]} \\
K_{\mathrm{M}} & =\frac{[\mathrm{E} . \mathrm{I}][\mathrm{S}]}{[\mathrm{E} . \mathrm{S} . \mathrm{I}]} \\
K_{\mathrm{I}} & =\frac{[\mathrm{E}][\mathrm{I}]}{[\mathrm{E} . \mathrm{I}]} \\
K_{\mathrm{I}} & =\frac{[\mathrm{E} . \mathrm{S}][\mathrm{I}]}{[\mathrm{E} . \mathrm{S} . \mathrm{I}]}
\end{aligned}
$$

As enzyme concentration is not changing; hence, it can be stated as:

$$
\left[\mathrm{E}_{\mathrm{T}}\right]=[\mathrm{E}]+[\text { E. S }]+[\text { E. I }]+[\text { E. S. I }]
$$

By substituting concentrations with the corresponding equilibrium terms and rearranging Equation 5:

The product formation rate $r_{p}=\frac{k[\mathrm{E} . \mathrm{S}]}{K_{\mathrm{M}}}$, therefore:

$$
[\mathrm{E}]=\frac{\left[\mathrm{E}_{\mathrm{T}}\right]}{1+\frac{[\mathrm{S}]}{K_{\mathrm{M}}}+\frac{[1]}{K_{\mathrm{I}}}+\frac{[\mathrm{S}][1]}{K_{\mathrm{I}} K_{\mathrm{M}}}}
$$

$$
r_{p}=\frac{k\left[E_{T}\right][S]}{K_{m}}
$$

moreover, $k\left[\mathrm{E}_{\mathrm{T}}\right]$ can be expressed as $V_{\max }$, and the Equation (3.8) turns out to be:

$$
V=\frac{V_{\max }}{\left(K_{\mathrm{M}}+[\mathrm{S}]\right)\left(1+\frac{[\mathrm{II}]}{K_{\mathrm{I}}}\right.}
$$

The equation could be arranged in linear relation (Gonze \& Kaufman, 2016):

$$
\frac{1}{V}=\frac{1}{[\mathrm{~S}]}\left(\frac{K_{\mathrm{M}}\left(1+\frac{[\mathrm{I}]}{K_{\mathrm{I}}}\right)}{V_{\max }}\right)+\frac{1}{V_{\max }}\left(1+\frac{[\mathrm{I}]}{K_{\mathrm{I}}}\right)
$$

In this case, the mixed inhibition could be expressed through the modifications:

$$
K_{\mathrm{M}}{ }^{\prime}=K_{\mathrm{M}}\left[1+\frac{[\mathrm{I}]}{K_{\mathrm{I}}}\right] \text { and } K_{\mathrm{M}}=\frac{1}{K_{\mathrm{S}}}
$$

Where $K_{\mathrm{s}}$ is the term describing enzyme dissociation constant (from E.S or E.I).

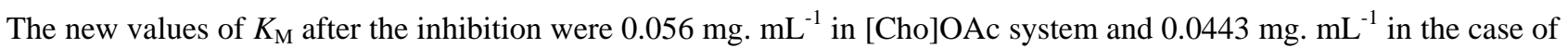
[EMIM]DEP with CMC. The value of $K_{s}$ was $22.22 \mathrm{~min}^{-1}, K_{\mathrm{s}}{ }^{\prime}$ is $17.86 \mathrm{~min}^{-1}$, and since the concentration of the presumed inhibitor (IL), is known throughout the reaction, $K_{\mathrm{I}}$ was calculated at $0.409 \mathrm{~min}^{-1}$. The catalytic efficiency $\left(k_{\text {cat }} K_{\mathrm{M}}\right)$ decreased from 30.71 to $24.46 \mathrm{~min}^{-1} \mathrm{mg}^{-1} \mathrm{ml}^{-1}$ in the presence of [Cho]OAc and increased to $31.86 \mathrm{~min}^{-1} \mathrm{mg}^{-1} \mathrm{~mL}^{-1}$ in [EMIM]DEP. The maximum $k_{\mathrm{cat}} / K_{\mathrm{M}}$ value of an enzyme is $10^{8}-10^{9} \mathrm{M}^{-1} \mathrm{~s}^{-1}$, and it is an indicator of the enzyme catalytic efficiency.

It was observed in this study that the activity reduced IL concentration increases (Figure 5), which indicated that the enzyme affinity towards the substrate decreased. Nonetheless, though the [Cho]OAc resulted in slight inhibition, the $K_{\mathrm{M}}$ and $V_{\max }$, did not change remarkably. 


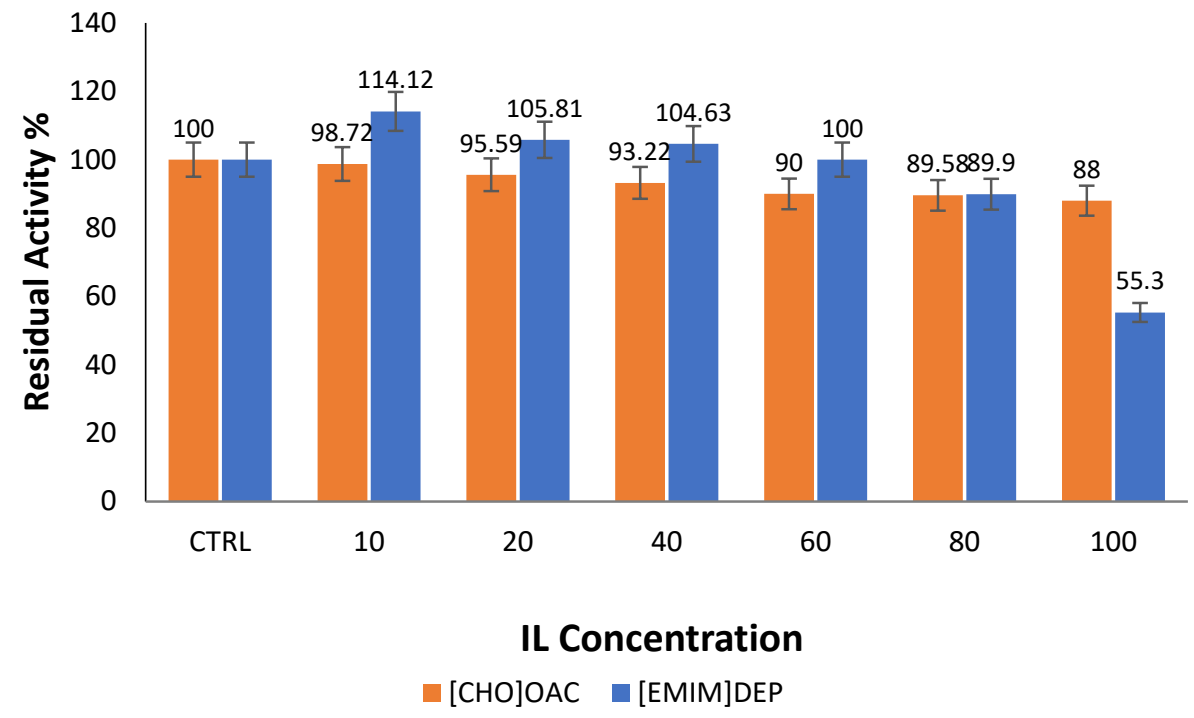

Figure 5. Effect of various concentrations of ILs [EMIM]DEP, [Cho]OAc on the cellulase activity compared to the buffer solution. $\mathrm{CTRL}=$ control

The changes were different in the presence of [EMIM]DEP as it slightly increased the $V_{\max }$ and did not significantly affect the affinity. It was reported that higher concentration of the substrate could promote surface accessibility and cellulases binding sites, hence, preventing inactivation effect. This could be able to explain the hydrolysis continuation for $48 \mathrm{~h}$ and the production of sugars regardless of the IL presence in the hydrolysis vessel (Elgharbawy et al., 2016). The slight impact of IL could also be explained by binding of IL anion to the lignin instead of the enzyme and therefore, the more free enzyme would be available which rescues the inactivation effect. Moreover, cellulase is surrounded by water molecules in the aqueous-IL system which could reduce the inhibition caused by IL or lignin (Zhao, 2016) as illustrated in Figure 6 which also explained the pattern in this study. It can be observed that [Cho]OAc has a slight inhibitory effect if compared to [EMIM]DEP. This could be a result of the composition of the IL. [Cho]OAc consists of cholinium cations and acetate anions, and the former is derived from choline chloride, which is part of the vitamin-B complex, the latter is derived from

intercellular metabolites. [Cho]OAc is a completely bioderived IL, which is more biocompatible, compared to imidazolium-based IL, [EMIM]DEP. This might also explain the behavior of the enzyme when water is added in both ILs (Asakawa et al., 2015). Enzymes usually require a certain amount of water in order to function in a particular reaction

(Kohno, Saita, Murata, Nakamura, \& Ohno, 2011).

It was inferred by Engel et al. that the activity of T. reesei cellulase reduced to 15-30\% in IL concentration of 10\% (Engel et al., 2010). Their group have investigated the [DMIM]DMP effect on individual cellulases and showed that the $\beta$-glucosidase, cellobiohydrolase and endoglucanase retained $34 \%, 60 \%$, and $63 \%$ of their relative activities in $10 \%$ [DMIM]DMP (Engel, Krull, Seiferheld, \& Spiess, 2012). Furthermore, Hu et al. (2016) showed that low concentration of [EMIM]DEP has a reversible inactivation on endoglucanases, and they supported that by SDS-PAGE, however, irreversible effect took place at a high concentration of the IL (more than 40\%).

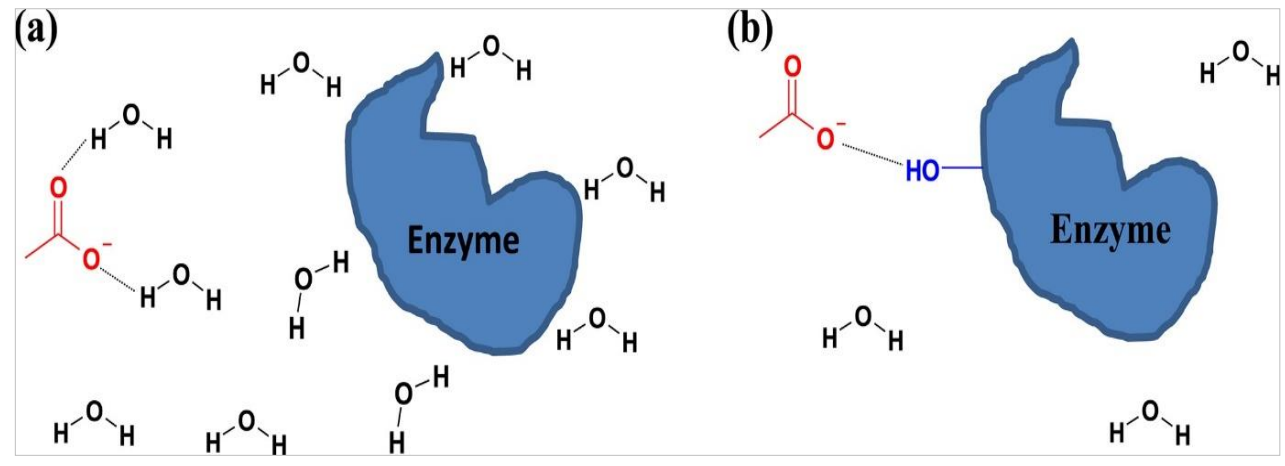

Figure 6. Illustration of interactions of the enzyme in acetate-containing IL: (a) between acetate anion with water molecules in diluted IL solution, and (b) between acetate anion and enzyme molecule in concentrated IL. Adapted from (Zhao, 2016) with permission from Wiley 
Some hydrolases, such as certain lipases and chymotrypsin, retained their activity in pure IL or might show better enantioselectivity, thermal stability or selectivity, compared to traditional solvents. Nonetheless, few studies have reported tolerating cellulases that could withstand high concentrations IL (Hu et al., 2016). Furthermore, to date, the activity of commercial cellulases in [EMIM]OAc, [BMIM]Cl, [DMIM]DMP and [AMIM]Cl were reportedly used as pretreatment of cellulose.

The kinetic constants for endoglucanase using different substrates have been documented. $V_{\max }$ values were 18,46 and 37 $\mu \mathrm{mol}^{-1}$. mg protein ${ }^{-1}$ with $\mathrm{CMC}, \beta$-glucan and xyloglucan, respectively. The value of $K_{\mathrm{M}}$ was $13.3 \mathrm{mg} . \mathrm{mL}^{-1}, 3.5 \mathrm{mg} . \mathrm{mL}^{-1}$ and $5.66 \mathrm{mg}$. mL ${ }^{-1}$ with the same substrates order. The value of $k_{\text {cat }}$ was between 5.6 and $11.5 \mathrm{~min}^{-1}$, and $k_{\text {cat }} / K_{\mathrm{M}}$ was between 42 to 400 . Reports have also revealed that endoglucanases vary in their affinity towards polysaccharides as supported by the observed values of $K_{\mathrm{M}}$ (Kaur, Oberoi, \& Chadha, 2015). Glucose and [EMIM]OAc acted as uncompetitive inhibitors for $\beta$-glucosidase (BG), which in this context indicated the probability of IL binding to the E-S complex. Most of the reported BG(s) are competitively inhibited by glucose; however, a non-competitive inhibition was also reported. Cellulase enzyme from Bacillus sp., MSL2 strain, from rice paddy field soil (48 kDa) retained $77 \%$ of its activity in [EMIM]OAc. The kinetic parameters of the purified enzyme revealed that the $V_{\max }$ was $1000 \mu \mathrm{M}$. $\min ^{-1}$, while $K_{\mathrm{M}}$ value was $0.8 \mathrm{mg} . \mathrm{mL}^{-1}$ (Sriariyanun, Tantayotai, Yasurin, Pornwongthong, \& Cheenkachorn, 2016). The types and concentration of inhibitors released throughout the pretreatment of lignocellulose depend on the composition of biomass, reaction conditions and pretreatment method.

It can be concluded that IL systems with a small concentration of certain ions can contribute to supernatural alteration in enzyme enantioselectivity or activity. Hence, ILs may be precisely adjusted for anticipated applications in biocatalysis. For instance, chloride anions are not suitable for cellulase stability while acetate and phosphate showed good compatibility to a certain level. Selecting the appropriate IL for the enzymatic reaction is one of the most important key factors for IL-enzyme catalyzed reactions.

\section{Conclusions}

The IL presence in the hydrolysis vessel did not result in irreversible inhibition. Promising activities were recorded in both [EMIM] DEP and choline acetate [Cho]OAc. The kinetic study of the one-step hydrolysis showed that the ILs result in a non-competitive mixed inhibition in which both $V_{\max }$ and $K_{\mathrm{M}}$ and are changed compared to the non-IL reaction. In both cases, the study proved that IL did not result in a severe loss of the activity of cellulase as $V_{\max }$ was not dropped dramatically nor the affinity. The study showed that a small amount of water is necessary in order to prevent the inhibition and activate the cellulase in the reaction medium that contains IL. More studies in terms of molecular simulation and modelling are required to generate a clear understanding of the cellulase behavior in ILs.

\section{References}

Alam, M. Z., Kabbashi, N. A., \& Hussin, S. N. (2009). Production of bioethanol by direct bioconversion of oil-palm industrial effluent in a stirred-tank bioreactor. J Ind Microbiol Biotechnol, 36(6), 801-808. https://doi.org/10.1007/s10295-009-0554-7

Alonso, D. M., Bond, J. Q., \& Dumesic, J. A. (2010). Catalytic conversion of biomass to biofuels. Green Chemistry, 12(9), 1493-1513. https://doi.org/10.1039/c004654j

Asakawa, A., Kohara, M., Sasaki, C., Asada, C., \& Nakamura, Y. (2015). Comparison of choline acetate ionic liquid pretreatment with various pretreatments for enhancing the enzymatic saccharification of sugarcane bagasse. Industrial Crops and Products, 71, 147-152. https://doi.org/10.1016/j.indcrop.2015.03.073

Balat, M. (2011). Production of bioethanol from lignocellulosic materials via the biochemical pathway: A review. Energy Conversion and Management, 52(2), 858-875. https://doi.org/10.1016/j.enconman.2010.08.013

Barakat, A., Mayer-Laigle, C., Solhy, A., Arancon, R. A. D., de Vries, H., \& Luque, R. (2014). Mechanical pretreatments of lignocellulosic biomass: towards facile and environmentally sound technologies for biofuels production. RSC Advances, 4(89), 48109-48127. https://doi.org/10.1039/C4RA07568D

Brodeur, G., Yau, E., Badal, K., Collier, J., Ramachandran, K. B., \& Ramakrishnan, S. (2011). Chemical and physicochemical pretreatment of lignocellulosic biomass: a review. Enzyme Research, 2011, 787532. https://doi.org/10.4061/2011/787532

Elgharbawy, A. A., Alam, M. Z., Moniruzzaman, M., \& Goto, M. (2016). Ionic liquid pretreatment as emerging approaches for enhanced enzymatic hydrolysis of lignocellulosic biomass. Biochemical Engineering Journal, 109, 252-267. https://doi.org/10.1016/j.bej.2016.01.021

Elgharbawy, A. A., Alam, Z., Jamal, P., Kabbashi, N. A., \& Moniruzzaman, M. (2016). Evaluation of the Ionic Liquids for in-situ Hydrolysis of Lignocellulosic Biomass by a Locally-produced Cellulase from Trichoderma reesei. 79-81. 
https://doi.org/10.1007/s13205-016-0440-8

Engel, P., Krull, S., Seiferheld, B., \& Spiess, A. C. (2012). Rational approach to optimize cellulase mixtures for hydrolysis of regenerated cellulose containing residual ionic liquid. Bioresource Technology, 115(0), 27-34. https://doi.org/10.1016/j.biortech.2011.10.080

Engel, P., Mladenov, R., Wulfhorst, H., Jäger, G., \& Spiess, A. C. (2010). Point by point analysis: how ionic liquid affects the enzymatic hydrolysis of native and modified cellulose. Green Chemistry, 12(11), 1959. https://doi.org/10.1039/c0gc00135j

Fu, D., Mazza, G., \& Tamaki, Y. (2010). Lignin extraction from straw by ionic liquids and enzymatic hydrolysis of the cellulosic residues. Journal of Agricultural and Food Chemistry, 58(5), 2915-2922. https://doi.org/10.1021/jf903616y

Galbe, M., \& Zacchi, G. (2007). Pretreatment of lignocellulosic materials for efficient bioethanol production. Adv Biochem Eng Biotechnol, 108, 41-65. https://doi.org/10.1007/10_2007_070

Gonze, D., \& Kaufman, M. (2016). Chemical and enzyme kinetics.

Gunny, A. A. N., Arbain, D., Edwin Gumba, R., Jong, B. C., \& Jamal, P. (2014). Potential halophilic cellulases for in situ enzymatic saccharification of ionic liquids pretreated lignocelluloses. Bioresource Technology, 155(0), 177181. https://doi.org/10.1016/j.biortech.2013.12.101

Harun, R., \& Danquah, M. K. (2011). Influence of acid pre-treatment on microalgal biomass for bioethanol production. Process Biochemistry, 46(1), 304-309. https://doi.org/10.1016/j.procbio.2010.08.027

Henderson, P. J. F. (1972). A linear equation that describes the steady-state kinetics of enzymes and subcellular particles interacting with tightly bound inhibitors. Biochemical Journal, 127(2), 321-333. https://doi.org/10.1042/bj1270321

Hu, D., Xiao, L., Li, L., Zhong, C., Ju, X., Yan, L., \& Hu, Z. (2016). Effects of Ionic Liquid 1-Ethyl-3-Methylimidazolium Diethylphosphate on Cellulase Produced by Paenibacillus sp. LLZ1. ACS Sustainable Chemistry \& Engineering, 4(9), 4922-4926. https://doi.org/10.1021/acssuschemeng.6b01229

Ibrahim, F., Moniruzzaman, M., Yusup, S., \& Uemura, Y. (2015). Dissolution of cellulose with ionic liquid in pressurized cell. Journal of Molecular Liquids, 211, 370-372. https://doi.org/10.1016/j.molliq.2015.07.041

Kaur, B., Oberoi, H. S., \& Chadha, B. S. (2015). Comparative analysis of two catalytically distinct endoglucanases from Aspergillus nidulans. J Appl Biol Biotechnol, 3, 22-29. https://doi.org/10.7324/JABB.2015.3205

Kohno, Y., Saita, S., Murata, K., Nakamura, N., \& Ohno, H. (2011). Extraction of proteins with temperature sensitive and reversible phase change of ionic liquid/water mixture. Polymer Chemistry, 2(4), 862-867. https://doi.org/10.1039/c0py00364f

Mamman, A. S., Lee, J., Kim, Y., Hwang, I. T., Park, N., Hwang, Y. K., \& Hwang, J. (2008). Furfural: Hemicellulose/xylosederived biochemical. Biofuels, Bioproducts and Biorefining, 2(5), 438-454. https://doi.org/10.1007/978-94-007-6052-3_6

Muhammad, N., Elsheikh, Y. A., Mutalib, M. I. A., Bazmi, A. A., Khan, R. A., Khan, H., \& khan, I. (2014). An overview of the role of ionic liquids in biodiesel reactions. Journal of Industrial and Engineering Chemistry. Retrieved

from http://www.scopus.com/inward/record.url?eid=2-s2.0-84894433658\&partnerID=40\&md5=1047f7fdf940ca9fe593 beb40ac50514

Nemestóthy, N., Megyeri, G., Bakonyi, P., Lakatos, P., Koók, L., Polakovic, M., \& Bélafi-Bakó, K. (2017). Enzyme kinetics approach to assess biocatalyst inhibition and deactivation caused by $[\mathrm{bmim}][\mathrm{Cl}]$ ionic liquid during cellulose hydrolysis. Bioresource Technology, 229, 190-195. https://doi.org/10.1016/j.biortech.2017.01.004

Ninomiya, K., Inoue, K., Aomori, Y., Ohnishi, A., Ogino, C., Shimizu, N., \& Takahashi, K. (2015). Characterization of fractionated biomass component and recovered ionic liquid during repeated process of cholinium ionic liquid-assisted pretreatment and fractionation. Chemical Engineering Journal, 259(0), 323-329. https://doi.org/10.1016/j.cej.2014.07.122

Noori, M. S., \& Karimi, K. (2016). Detailed study of efficient ethanol production from elmwood by alkali pretreatment. Biochemical Engineering Journal, 105, 197-204. https://doi.org/10.1016/j.bej.2015.09.019

Pellera, F. M., \& Gidarakos, E. (2018). Chemical pretreatment of lignocellulosic agroindustrial waste for methane production. Waste Management, 71, 689-703. https://doi.org/10.1016/j.wasman.2017.04.038 
Salihu, A., \& Alam, M. Z. (2015). Solvent tolerant lipases: A review. Process Biochemistry, 50(1), 86-96. https://doi.org/10.1016/j.procbio.2014.10.019

Salvador, A. C., Santos, M. da C., \& Saraiva, J. A. (2010). Effect of the ionic liquid [bmim]Cl and high pressure on the activity of cellulase. Green Chemistry, 12(4), 632-635. https://doi.org/10.1039/b918879g

Sharma, V., Nargotra, P., \& Bajaj, B. K. (2019). Ultrasound and surfactant assisted ionic liquid pretreatment of sugarcane bagasse for enhancing saccharification using enzymes from an ionic liquid tolerant Aspergillus assiutensis VS34. Bioresource Technology, 285, 121319. https://doi.org/10.1016/j.biortech.2019.121319

Shi, J., Gladden, J. M., Sathitsuksanoh, N., Kambam, P., Sandoval, L., Mitra, D., \& Singh, S. (2013). One-pot ionic liquid pretreatment and saccharification of switchgrass. Green Chemistry, 15(9), 2579. https://doi.org/10.1039/c3gc40545a

Sriariyanun, M., Tantayotai, P., Yasurin, P., Pornwongthong, P., \& Cheenkachorn, K. (2016). Production, purification and characterization of an ionic liquid tolerant cellulase from Bacillus sp. isolated from rice paddy field soil. Electronic Journal of Biotechnology, 19, 23-28. https://doi.org/10.1016/j.ejbt.2015.11.002

Tan, H. T., Lee, K. T., \& Mohamed, A. R. (2011). Pretreatment of lignocellulosic palm biomass using a solvent-ionic liquid [BMIM] Cl for glucose recovery: An optimisation study using response surface methodology. Carbohydrate Polymers, 83(4), 1862-1868. https://doi.org/10.1016/j.carbpol.2010.10.052

Varanasi, P., Singh, P., Arora, R., Adams, P. D., Auer, M., Simmons, B. A., \& Singh, S. (2012). Understanding changes in lignin of Panicum virgatum and Eucalyptus globulus as a function of ionic liquid pretreatment. Bioresource Technology, 126(0), 156-161. https://doi.org/10.1016/j.biortech.2012.08.070

Wang, G., Post, W. M., Mayes, M. A., Frerichs, J. T., \& Sindhu, J. (2012). Parameter estimation for models of ligninolytic and cellulolytic enzyme kinetics. Soil Biology and Biochemistry, 48, 28-38. https://doi.org/10.1016/j.soilbio.2012.01.011

Wang, Y., Radosevich, M., Hayes, D., \& Labbé, N. (2011). Compatible Ionic liquid-cellulases system for hydrolysis of lignocellulosic biomass. Biotechnology and Bioengineering, 108(5), 1042-1048. https://doi.org/10.1002/bit.23045

Yang, F., Li, L., Li, Q., Tan, W., Liu, W., \& Xian, M. (2010). Enhancement of enzymatic in situ saccharification of cellulose in aqueous-ionic liquid media by ultrasonic intensification. Carbohydrate Polymers, 81(2), 311-316. https://doi.org/10.1007/s10529-008-9638-0

Zainan, N. H., Alam, Z., \& Al-Khatib, M. F. (2013). Production of sugar by hydrolysis of empty fruit bunches using palm oil mill effluent (POME) based cellulases: Optimization study. African Journal of Biotechnology, 10(81), 18722-18727. doi.org/10.5897/AJB11.2744.

Zhang, Y. H. P., Hong, J., \& Ye, X. (2009). Cellulase assays. In: Mielenz J. (eds) Biofuels. Methods in Molecular Biology (Methods and Protocols) (pp. 213-231). Totowa, NJ: Springer. https://doi.org/10.1007/978-1-60761-214-8_14

Zhao, H. (2016). Protein stabilization and enzyme activation in ionic liquids: specific ion effects. Journal of Chemical Technology \& Biotechnology, 91, 25-50. https://doi.org/10.1002/jctb.4837

Zhao, H., Jones, C. L., Baker, G. A., Xia, S., Olubajo, O., \& Person, V. N. (2009). Regenerating cellulose from ionic liquids for an accelerated enzymatic hydrolysis. Journal of Biotechnology, 139(1), 47-54.

https://doi.org/10.1016/j.jbiotec.2008.08.009

\section{Copyrights}

Copyright for this article is retained by the author(s), with first publication rights granted to the journal.

This is an open-access article distributed under the terms and conditions of the Creative Commons Attribution license (http://creativecommons.org/licenses/by/4.0/). 